\title{
Getting on the ground: Exploring the determinants of utility-scale solar PV in Rwanda
}

\author{
Rodriguez Manotas, Judit; Bhamidipati, Padmasai Lakshmi; Haselip, James Arthur
}

\section{Published in:}

Energy Research \& Social Science

Link to article, DOI:

10.1016/j.erss.2018.03.007

Publication date:

2018

Document Version

Peer reviewed version

Link back to DTU Orbit

Citation $(A P A)$ :

Rodriguez Manotas, J., Bhamidipati, P. L., \& Haselip, J. A. (2018). Getting on the ground: Exploring the determinants of utility-scale solar PV in Rwanda. Energy Research \& Social Science, 42, 70-79.

https://doi.org/10.1016/j.erss.2018.03.007

\section{General rights}

Copyright and moral rights for the publications made accessible in the public portal are retained by the authors and/or other copyright owners and it is a condition of accessing publications that users recognise and abide by the legal requirements associated with these rights.

- Users may download and print one copy of any publication from the public portal for the purpose of private study or research.

- You may not further distribute the material or use it for any profit-making activity or commercial gain

- You may freely distribute the URL identifying the publication in the public portal 


\title{
Getting on the ground: exploring the determinants of large scale solar PV in Rwanda
}

\begin{abstract}
Solar PV is gaining ground in developing countries, especially in sub-Saharan Africa where a change from donor to more market-driven large-scale projects has been observed. This article contributes to the energy transition research in developing countries, taking Rwanda as a case study and focusing on large-scale on-grid solar projects. The multi-level perspective (MLP) is used to structure our analysis of the various socio-technical levels, and their interaction, to better understand the conditions that are enabling this transition. Specifically, we focus on the Rwamagana solar power plant, the largest on-grid solar power plant in East Africa, from inception to operation. Our analysis reveals the central importance of government support; both politically and financially, and through its provision of legal guarantees that helped reduce investment risk for the Rwamagana plant. These aspects are usually underplayed or overlooked within the MLP framework. We also focus our analysis on the aspect of control and driving forces, in particular the role of private sector project champions. Key roles were also played by development partners and private investors, sharing a vision and willingness to make the project happen, setting an example for other African countries to follow.
\end{abstract}

\section{Introduction}

According to the Africa Energy Outlook (IEA, 2014), sub-Saharan Africa (SSA) is the only region in the world where the amount of people without access to electricity - more than 620 million in 2014 - is increasing, i.e. where population growth is outstripping the rate at which people are gaining access to modern energy services. Solid biomass remains the dominant source of domestic energy use, mainly used for cooking. The significant technical potential for renewable energies in SSA opens the door for the development of non-fossil fuel electricity generation projects based on such technologies, 'leapfrogging' in the transition to a low-carbon energy system (IEA, 2014; Marquardt, 2015).

Investment in PV in Africa has increased in the last decade due to falling costs as the technology matures (IEA, 2014). Donor agencies have been key players in financing energy projects in Africa, but an apparent switch from donor-driven to market-driven large-scale solar projects has been observed, which would appear to indicate a trend towards greater investment in these kinds of projects, especially since 2011 (Eberhard et al., 2016). This new trend for foreign direct investment (FDI) is based on turn-key plants delivered and operated by foreign project developers, typically under Power Purchase Agreements (PPA) with national utilities (Hansen et al., 2014). This article focuses on the case of Rwanda in order to strengthen the empirical basis for understanding this ongoing technological 'transition'.

Specifically, we seek to answer two main research questions: 1. What type of transition pathway is taking place in the case of large-scale PV in Rwanda? 2. How have 
the key players and institutions involved in decision-making influenced each other in reaching that outcome?

Through an application of the multi-level perspective (MLP) framework and political economy, we seek to explore how and why we are observing this transition, i.e. what are the critical factors at the landscape and regime level that are creating the conditions for the transition towards large-scale PV power in Rwanda? What are the impeding and enabling conditions for this transition? What was the role/involvement of different local/national and transnational actors in what was the first utility-scale solar plant in Rwanda?

Our aim with this article is to explore, in detail, how the Rwamagana project came into being and to understand the extent to which it qualifies as a market-driven investment indicative of a wider trend towards a low-carbon energy transition in SSA.

\section{The transition to low-carbon energy technologies}

Research into energy 'transitions' is a relatively new field (Grubler, 2012). However, most attention on low-carbon energy transitions has been in developed countries, especially in northern Europe. Verbong \& Geels (2007) and Bosmana et al. (2014) studied the transition of the Dutch electricity system; Kern (2012) and Geels et al. (2016) analysed the case of the UK; and Strunz (2014) and Wassermann et al. (2015) focused on the German energy transition, among others.

While some important studies have been conducted in Africa, there is an uneven geographical spread. Indeed the majority of studies have focussed on South Africa and Kenya (Byrne, 2011; Baker, 2012; Ulsrud, 2015; Newell, 2016), hence, the trajectory and experience of transitions in other African countries are relatively less understood.

Large-scale solar PV projects are of interest in Rwanda since the construction of the first of its kind - the Rwamagana solar plant - in the Eastern part of the country. However, only the diffusion of biogas technology (Tigabu et al., 2015) and off-grid solar PV in the country (Jacobsson, 2013) have been studied so far from an energy transition approach. As described by Jacobsson (2013), the government of Rwanda has worked closely with a variety of western donors to promote a range of renewable and alternative energy technologies. However, the Rwamagana solar plant was developed and financed through private sector leadership and risk taking, thus appearing to mark a break from donor-led to market-led investment.

\section{Energy and electricity in Rwanda}

In 2016 Rwanda had a population of 11.5 million, predominantly rural (83.5\%), with a relatively high population density of 471 inhabitants per $\mathrm{km}^{2}$ (World Bank, 2014). Rwanda is classified as a low-income country with a GDP per capita of \$697.3 in 2015 (World Bank, 2015). However, between 2001 and 2015 real GDP grew 8\% per annum on average, including strong growth rates in recent years of $7 \%$ in 2014 and $6.9 \%$ in 2015, up from $4.7 \%$ in 2013 (World Bank, 2016a). According to the World Bank's Doing Business report for 2016, Rwanda was the second 'most-improved' country in the world and the most improved among those surveyed in SSA. The World Bank also considers Rwanda to be the best performing country in East and Central Africa, and the second easiest place to do business in Africa (World Bank, 2016b). 
Energy consumption in Rwanda consists of biomass, oil, gas and electricity. Biomass is the main primary energy source in the country and accounts for $85 \%$ of all energy needs (MININFRA, 2015a). In 2012 electricity only accounted for about $4 \%$ of the total energy consumed (MININFRA, 2015b). Electricity is generated mainly by hydropower $(47 \%)$, while the rest comes from diesel-powered generators $(27 \%)$, methane (14\%) - mainly from the Kivuwatt project in Lake Kivu - and other sources, including solar power (REG, 2017).

Rwanda had an electricity generation capacity of 160 MW in 2015 (MININFRA, 2015b), which increased to $216 \mathrm{MW}$ by 2017 (REG, 2017). According to the Energy Sector Strategic Plan (2015), Rwanda aims to reach $563 \mathrm{MW}$ of generation capacity by 2018 . The roadmap includes, among others, the installation of about $40 \mathrm{MW}$ from solar power plants during the period 2014-2018 (MININFRA, 2015b). Nevertheless, this target is unlikely to be met since $347 \mathrm{MW}$ are yet to be installed.

In terms of access to electricity, more than $60 \%$ of the urban population is gridconnected (World Bank, 2012a), but this falls to 7.7\% in rural areas (World Bank, 2012b). The majority of the Rwandan population live in small villages, mostly unconnected to the grid. The country has ambitious plans to electrify at least $70 \%$ of all households by 2018 , aiming to provide on-grid access to $48 \%$ of households and off-grid to $22 \%$ of households (MININFRA, 2015b). But again these targets are unlikely to be met on time.

Major electricity consumers in the country are households $(51 \%)$ and the industrial sector $(42 \%)$, including companies in the cement, mining, textile and agricultural sector (MININFRA, 2015b). Before 2017 the average wholesale electricity grid price was $\$ 0.24 / \mathrm{kWh}$, which was relatively high for the region. Electricity tariffs were not cost reflective and were heavily subsidized due to the relatively large share of diesel-based power generation. The government estimated that the real cost of electricity in Rwanda was at that time 50\% higher than the average cost in East Africa (MININFRA, 2015b). However, from January 2017 the government established a new electricity tariff - distinguishing residential, non-residential and industrial users which depends on consumption blocks and time of consumption (only for industrial users). For residential users electricity price from $0-15 \mathrm{kWh}$ is $\$ 0.10 / \mathrm{kWh}$, from $15-50$ $\mathrm{kWh}$ is $\$ 0.216 / \mathrm{kWh}$ and above $15 \mathrm{kWh}$ is $\$ 0.224 / \mathrm{kWh}$ (RURA, 2016). The Rwanda Energy Group (REG) is the energy utility in the country, and has two subsidiaries: EDCL and EUCL. The first one manages energy production, whereas the second one manages energy maintenance, and plays an important role in the execution of PPAs with IPPs. (REG, 2015).

\section{Energy transitions}

Energy transitions are defined by Geels (2011) as form of socio-technical transition, as they involve transformations in the overall configuration of the energy system. In other words, not only technology and infrastructure are included, but also policy, markets, consumer practices, cultural meaning and scientific knowledge, making them complex and long-term processes. It is therefore essential to understand the multi-dimensional nature of energy transitions and the dynamics of structural change more broadly (Geels, 2011).

Transitions and system changes can be explained by different theories. The Multi-Level Perspective (MLP), the Strategic Niche Management (SNM) and the 
Technological Innovation System (TIS) theories are all useful and relevant theories, applicable to a developing country context. Several studies have already been carried out in order to analyse the introduction of different renewable energy technologies in developing countries, mainly in Asia (Jolly et al., 2012; Ulsrud et al., 2011; Mohamad, 2011). Some authors have also studied the transitions in African countries, but the number of studies is relatively small (Baker et al., 2014; Jacobsson, 2013; Byrne 2014; Pueyo, 2015). African countries, and more specifically sub-Saharan countries, which are currently in a potential phase of low-carbon energy development, are an understudied area.

We assume that the starting point for analysing an energy transition is different for less developed countries, since OECD economies already have established energy systems which are expected to decarbonise over time. Meanwhile, developing countries, especially in SSA, remain highly reliant on traditional energy sources and technologies, and electrification rates are often below 50\%. Other key aspects in a developing country context include:

- Greater dependence on donor interventions

- Different political and economic circumstances, including many non-stable democracies

- Presence of competing development interests

- Lower levels of technical and institutional capacity

- Weaker institutions, lower levels of transparency and higher levels of perceived corruption

- Weaker negotiating powers in global dialogues

- Greater dependence on foreign sources of technology and finance

- Different business models

\section{The Multi-Level Perspective (MLP) and Transition Pathways}

In this paper we apply the MLP framework as it enables us to capture bigger picture processes, of interest to us in studying a relatively small country. The MLP framework "conceptualizes overall dynamic patterns in socio-technical transitions" (Geels, 2011, p.26). The MLP defines transitions "as outcomes of alignments between developments at multiple levels", being a non-linear process (Geels \& Schot, 2007, p.399; Geels, 2011). This interaction is based on three different levels from a macro to a micro perspective:

- The landscape level, the wider context, includes slowly changing external factors which influence the development of the energy system - i.e. regime and niche levels - and are beyond individual actors. These can be macro-economic trends, macropolitical developments, socio-economic trends and deep cultural patterns (Geels, 2011; Kern, 2012).

- The regime level provides the stability of an existing socio-technical system (Geels, 2004). It is based on three dimensions: (i) formal, normative and cognitive rules (e.g. regulations, standards, laws, guiding principles), (ii) material and technical elements (e.g. resources, grid, generation plants) and (iii) actors and social networks (e.g. energy utility, Ministry of Infrastructure) (Verbong \& Geels, 2007; Kern, 2012). 
- The niche level refers to new energy practices and technological innovations. It comprises learning processes, price-performance improvements, support from powerful groups and the establishment of market niches (Kern, 2012). However, sometimes it is difficult to introduce new niches as the existing regime is stabilized by lock-in mechanisms and new niches do not fit with the existing regime (Geels, 2011).

Here, we refer to the four 'classic' transition pathways that are based on the nature of interaction (reinforcing or disruptive) between niche-innovations and landscape pressure with the regime, and the timing of these interactions (Geels \& Schot, 2007).

- Transformation path: A moderate landscape pressure (disruptive change) takes place, but niche-innovations cannot take advantage of it as they are not yet sufficiently developed.

- Reconfiguration path: Radical innovations which are developed in niches are initially adopted in the regime level as add-ons or complements to solve small problems or improve performance.

- De-alignment and re-alignment path: A large and sudden change takes place in the landscape level, causing a de-alignment of the regime. In this case multiple nicheinnovations can co-exist and compete until one gains momentum and becomes the dominant.

- Technological substitution: A specific shock in the landscape level takes place. Niche-innovations are sufficiently developed and have gathered internal momentum, resulting in the replacement of the existing regime.

The transition pathways approach has also been used, particularly in the context of the UK energy/electricity system, to envision and drive low-carbon scenarios. Here, a set of 3 different pathways were developed and analysed to examine the role of electricity within the context of transition pathways to a low carbon economy, named market rules (market), central coordination (government) and a thousand flowers (civil society). Each pathway reflects the outcome of multitudes of decisions made by interacting actors along the way (Foxon et.al. 2013).

These transition pathways have recently been reformulated by Geels et al. (2016) based on the idea that they should not have only a 'global'/ 'outside-in' conceptual logic, but also a 'local'/ 'inside-out' conceptual logic. The first one represents the general development processes of an innovation, while the second one focuses more on the immediate processes that lead to particular development episodes, as described by Poole \& Van de Ven (1989). The reformulation of the transition pathways is built upon "who the dominant actors are and how they shape the reproduction or change of rules and institutions", basically in terms of actors, technologies and institutions (Geels et al., 2016, p.897). We bring in these ideas to counter the claim that the MLP framework does not take into account agency, conflict and struggle, i.e. that the MLP and the transitions literature more broadly often fail to recognise or account for the explicitly political nature of socio-technical transitions. 


\section{Methodology}

The timespan of our secondary data analysis covered the period from the end of the genocide against the Tutsis (1994) to the last year of Vision 2020 (2020) (Republic of Rwanda, 2012), a roadmap for the development of the country. Nevertheless, the past five years were of particular interest (2011-2016), as many new policies and laws entered into force and new relevant energy projects were planned and constructed.

Primary data collection was undertaken in Rwanda between June and July 2016, with 12 in-depth semi-structured interviews conducted with key stakeholders and decision makers, including the project developers. In total, twelve experts were interviewed from private companies - Scatec Solar, Afritech Energy, Climate Concern, Remote Group, Hobuka Ltd, GigaWatt Global - and agencies and ministries from the government of Rwanda - RURA, MINIRENA, RDB, REG (EDCL and EUCL). The aim of these was to develop a rich understanding of the various decision making processes (planning, political, financial etc.), the relative importance of various visions, targets, policy incentives and actors networks. Observations were also made during a site visit to the Rwamagana plant in July 2016.

The mix of qualitative primary data collection, combined with publically available secondary data was determined by the nature of the research questions and analytical framework, aims to critically examine the context, processes, actors and networks within the different socio-technical levels of the corresponding energy transition (Bryman, 2012).

\section{Analysis of Rwanda's successful large-scale solar power plant}

The Rwamagana solar power plant was the first major solar power plant in East Africa. It is also considered the fastest solar project in Africa, as it went from contract signing to construction and connection in less than a year. It is located $60 \mathrm{~km}$ east of Kigali, in the Rwamagana district. It has a generation capacity of $8.5 \mathrm{MW}$, and during the first year it produced approximately 15 million KWh (Scatec Solar, 2014).

\section{Inception of the project}

A combination of two key factors led to the initial idea for the development of the Rwamagana solar project. The Agahozo-Shalom Youth Village (ASYV) had a large area of land that was used for agriculture, but the benefits from it were not significant. At the same time, the founder of the youth village, Anne Heyman, had an interest in developing a solar power plant in that area. In February 2012 Anne Heyman was introduced to Chaim Motzen, former managing director of Gigawatt Global (GG), the developer of the project. GG is a multinational renewable energy company focused on the development and management of utility-scale solar fields in emerging markets.

Interest in renewable energy projects has increased worldwide, as well as in Rwanda resulting in a high-level political promotion of renewable energies in general and PV solar in particular. This can be considered as a landscape pressure to the sociotechnical energy system of the country, which is defined by climate change awareness and the Paris Agreement, and the uncertainty in oil prices and constant improvement of PV solar technology and reducing PV prices. Climate change awareness and international joint action highlight the importance of leaving behind fossil fuels and adopting a more renewable-based energy generation mix. The uncertainty in oil prices 
together with the rapid development of PV technology make this energy source more reliable and attractive, especially in countries with low or non-commercially attractive oil reserves, land-locked and far from the coast, such as Rwanda.

The need to increase electricity generation and access in the country is another landscape pressure. The political stability and rapid economic growth that followed the genocide against the Tutsis more than 20 years ago has enabled Rwanda develop faster than its neighbours, and the use of solar PV technology, at various scales, has been a priority technology for the government in recent years. However, the government's ambition for Rwanda to achieve the status of a middle-income country translates into political support for any technology that will increase electricity generation in a sustainable and affordable manner. The above-mentioned slowly changing external factors are a driver for transition as they apply a pressure, creating destabilizing effects on the regime level. This, in turn, can create opportunities for niches. The Rwamagana project is a result of a changing socio-technical energy regime.

It is widely acknowledged that governments have a key role in bringing about policy-driven energy transitions (Kern, 2012). Rwanda has established several policies and strategies, which have provided implicit and explicit support to on-grid PV solar power, as part of a broader drive towards a lower carbon energy system. At the broadest strategic level, the Green Growth and Climate Resilient Strategy 2012-2017 (2011) which aims to guide Rwanda towards becoming a "developed climate-resilient, low carbon economy" by 2050 (Republic of Rwanda, 2011, p.18), proposes to phase out oil and peatfuelled generation and promote renewable energies (Republic of Rwanda, 2011). Operating in support of the broader strategies is the Energy Sector Strategic Plan 2013/14-2017/18 (2015) which ensures the implementation of the targets in the energy sector established in EDPRS-II through concrete measures, and guides in the implementation of a National Energy Policy. It presents the strategies related to on-grid electricity supply, electricity access, environmental sustainability and electricity tariffs (MININFRA, 2015b). Thus, landscapes pressures are influencing the direction of policy objectives within the country.

Interest in developing a PV solar plant in the ASYV was also due to the great potential to generate electricity from solar PV that Rwanda has. Even though the country is located in the sub-Saharan region where the rainy season lasts approximately half of the year, average daily solar irradiation is between 4.3 and $5.2 \mathrm{kWh} / \mathrm{m} 2 /$ day. However, PV suitability - also taking slope and vegetation into account - varies significantly across the different regions, with the country's eastern province the most promising for PV (Museruka \& Mutabazi, 2007).

Land availability for developing the project was also a point in favour. Rwanda is a small country, and also one of the African countries with the highest population density. In addition, there are many large water bodies (Lake Kivu, Lake Burera, etc.) and national parks (Gishwati Forest National Park, Nyungwe Forest National Park, Akagera National Park) that further reduce the area available for construction of large scale PV. The combination of a lack of available land and its characteristics are considered the main physical barriers to the development of solar projects in the country.

GG's interest in a project like this was in part a result of a two-day Forum on the Energy Sector in February 2012 in Kigali, organised by the government of Rwanda (Gakwaya, 2012). The main goal of this conference was to attract private investors in the 
development of on-grid energy projects, as the country at that time was in urgent need of electricity generation capacity.

The promotion of participation of the private sector is present in many of Rwanda's strategies and policies. Firstly, there is the Rwanda Vision 2020 (2000, revised in 2012) which aims to promote economic development and stability, to reduce donor dependency. Private sector development and the role of foreign investment are considered central to achieving this goal (Republic of Rwanda, 2012). Secondly, the previously mentioned Green Growth and Climate Resilient Strategy 2012-2017 also proposes to incentivise private investment in renewable electricity by providing feed-in tariffs and long term PPAs to provide a secure investment environment for IPPs, and implement renewable energy norms and codes of practice in order to remove uncertainty for private sector investors and project developers (Republic of Rwanda, 2011). Thirdly, there is the Economic Development and Poverty Reduction Strategy EDPRS-II 2013-2018 - (ESSP, 2013) which also fosters private investment in the sector (MINECOFIN, 2013). The Energy Sector Strategic Plan 2013/14-2017/18 (2015) also presents actions to promote private sector engagement. Examples include updating the investment code, establishing the Rwandan Energy Development Fund for early-stage funding, and developing investment processes for IPP energy projects (MININFRA, 2015b). The Rwanda Energy Policy - REP (2015) focuses on the promotion of on-grid projects in order to improve electricity access for business and industrial users. Off-grid systems will be mainly used to provide electricity to rural households. One objective of the policy is the creation of "an enabling environment for increased private sector participation in energy supply and service provision" (MININFRA, 2015a, p.14). The government is aware of the importance of a clear legal and regulatory framework to increase investors' confidence in Rwanda, especially to attract foreign private investors. Consequently, the government plans to strengthen the legal and regulatory framework for renewable energy by "revising current legislation and putting in place new laws, regulations, and technical guidelines and standards" (MININFRA, 2015a, p.33).

When it comes to understanding the 'hard' rules and regulations in place in the Rwandan energy sector, it is necessary to step back from the multiple visions, strategies, plans and policies. Relevant to our discussion here is the Electricity Law (2011), which opened the electricity industry in Rwanda for private sector participation through investments in generation and grid projects, after law no. 18/99 of 30/o8/1999 liberalized the Rwandan energy market in 1999 (Parliament of Rwanda, 2011). Also central to our analysis is the Law on Investment Promotion and Facilitation (2015), which promotes and facilitates investment in Rwanda, and where energy is considered as one of the priority economic sectors. Particularly for operations related to solar energy generation, there is a preferential corporate income tax rate of $15 \%$ (Parliament of Rwanda, 2015a). Law $n^{\circ}{ }^{3} 4 / 2015$ of 30/o6/2015 establishing the infrastructure development levy on imported goods established that "industrial machinery and equipment for energy" and "specialised solar equipment and accessories" are exempted from the levy of $1.5 \%$ on the customs value of imported goods (Parliament of Rwanda, 2015b, p.7, 34). Law nº37/2012 of o9/11/2012 establishing the value added tax exempted some energy supply equipment, though solar PV was not included later modification in the code (Parliament of Rwanda, 2015c). Finally, the Rwanda Grid Code (2012) is a set of documents that determines technical and other requirements for the connection to and use of the grid. The connection requirements are based on the EAPP Interconnection Code to ensure the 
system is appropriate for future electrical power trading (RURA, 2012). However, the current Grid Code does not include renewable energy components. This has slowed the process of compliance, as PV project developers have been forced to seek an exemption (Abrams, 2016). However, when considering all the relevant strategies, policies and laws the overall picture is one of a state bureaucracy operating to encourage private and foreign investment and management, as a means to achieve 'green' economic growth and development.

The private sector is becoming more and more important for the development of solar projects in Rwanda, at all scales. Since the liberalisation of the electricity market in 1999 (Parliament of Rwanda, 2011), private companies have been able to generate electricity by owning and operating electricity generation facilities, operating as IPPs when supplying to the grid. There are many private developers of IPP power projects, both foreign and local, that work in Rwanda. Foreign private project developers tend to rely on foreign private capital, thus providing a source of foreign investment, which is a cornerstone of the government's economic development agenda.

\section{Development of the project}

GG conducted the technical design work and coordinated the feasibility study to analyse the project in technical and economic terms, while ASYV was in charge of the contacts and communications, and provided local expertise in the early phases. GG contacted the Rwanda Development Board (RDB) and expressed its interest in developing this project through an unsolicited Expression of Interest (EoI). Within a few months GG had signed a Memorandum of Understanding (MoU) with the Ministry of Infrastructure (MININFRA). This project did not follow a bidding process, instead it was directly negotiated. Competitively bid solar PV are usually more competitive than directly negotiated projects (e.g. South Africa and Uganda vs. Nigeria and Rwanda) (Eberhard et al., 2016). The Rwanda Energy Policy - REP (2015) states that the default procurement choice has to be a competitive bidding of all energy-related projects, including IPP generation projects, which should increase transparency and ensure value-for-money in the use of public funds (MININFRA, 2015a). Therefore, after the Rwamagana project was done, the government of Rwanda defined a more efficient procurement process. This change in the regime level might have been influenced by the development of this and other projects.

Various state agencies play an enabling role in the development of on-grid renewable energy projects (Table 1 ). These agencies are widely regarded as stable and reliable in terms of compliance with the law. This contributes to a propitious investment environment, translating into relatively low investment risk (Abrams, 2016).

Table 1. Main actors and their function, as they relate to the development of large-scale solar projects in Rwanda.

\begin{tabular}{cl}
\hline $\begin{array}{c}\text { Rwanda Energy } \\
\text { Group }\end{array}$ & $\cdot$ Providing technical assessment \\
\hline & Providing PPAs \\
$\begin{array}{c}\text { Rwanda Utilities } \\
\text { Regulatory } \\
\text { Authority }\end{array}$ & - Retting tariffs \\
& Provision of licenses, permits and \\
& authorizations \\
\hline
\end{tabular}




\begin{tabular}{|c|c|}
\hline $\begin{array}{l}\text { Rwanda } \\
\text { Development } \\
\text { Board }\end{array}$ & $\begin{array}{l}\text { - Promotion of private sector investment } \\
\text { - Investment process } \\
\text { - Guidance } \\
\text { - Facilitation } \\
\text { - Leading negotiations for strategic projects } \\
\text { - Issuing EIAs } \\
\text { - Designing incentives }\end{array}$ \\
\hline $\begin{array}{c}\text { Ministry of } \\
\text { Infrastructure }\end{array}$ & $\begin{array}{l}\text { - Policy and strategy formulation } \\
\text { - Granting both concessions and MoUs }\end{array}$ \\
\hline $\begin{array}{c}\text { Rwanda } \\
\text { Environmental } \\
\text { Management } \\
\text { Authority } \\
\end{array}$ & - Environmental regulations \\
\hline $\begin{array}{c}\text { Ministry of Finance } \\
\text { and Economic } \\
\text { Planning }\end{array}$ & $\begin{array}{l}\text { - Taxation formulation } \\
\text { - Granting Government Guarantees }\end{array}$ \\
\hline $\begin{array}{c}\text { Independent } \\
\text { Power Producers }\end{array}$ & $\begin{array}{l}\text { - Development of private energy projects } \\
\text { - Generation of electricity }\end{array}$ \\
\hline
\end{tabular}

GG submitted its feasibility study in December 2012 (Interview GG, 2016). The initial design of the power plant specified a generation capacity of $10 \mathrm{MW}$, but this was later reduced to $8.5 \mathrm{MW}$ for technical reasons related to the limited capacity of the national grid, at that location. The size and technical limitations of the electricity grid is also decisive for developing more large-scale solar projects. Increasing the grid coverage to supply electricity to rural villages will be costly and likely take many years. Therefore, increasing the country's generation capacity through large-scale solar projects in the short/mid-term will not help to provide electricity to the majority of the population, given the absence of grid coverage. Instead, the electricity generated by large-scale plants would be added to the total electricity capacity, mainly contributing to the development of the urban industrial sector. Another important factor for the implementation of large scale solar is the capacity of the grid to accept intermittent energy. Many investors had been interested in large-scale solar projects in Rwanda, but the government was not able to accept most of the proposals partly due to a potential excess of intermittent power in the grid. In relation to this, the construction of the Eastern Africa Power Pool (EAPP) - a common power grid among several countries in East Africa - will connect Rwanda to its neighbouring countries (EAPP, 2016). This connection would technically make possible the construction of more large-scale solar plants, as Rwanda could export the excess of solar energy generated, ironing out the supply and demand for electricity over a far larger geography, thus reducing the limitations of intermittent power supply from solar and wind resources.

A team of experts from EWSA (now the REG - Rwanda Energy Group) coordinated the project together with GG. They were in charge of analysing the proposal, facilitating site identification, assessing the equipment, approving the technical design and the feasibility study, and the Environmental and Social Impact Assessment. This phase could have taken years (and often does), but the strong willingness of the government to get the project completed was widely cited as the main enabler of speedy progress. 


\section{Commercial negotiations and financing}

After the feasibility study was approved by RDB, GG started commercial negotiations with RDB and REG. A variety of stakeholders were involved in those negotiations: (i) RDB in-house lawyers, (ii) the legal, technical and financial team from the public utility (REG), and (iii) a law firm that provided legal support to GG. According to the project developer both sides, the government and GG, were well prepared, which enabled them to produce a good PPA. This process took around four months to complete. GG works as an IPP and has a full license to operate (2014-2039) (RURA, 2016). The IPP model was new to Rwanda, at that time and the Rwamagana solar plant was the first IPP solar project to be built in Rwanda. The PPA included the following obligations: installing, supplying and maintaining the power plant, and providing a minimum of approximately 7 MW average available capacity.

The tariff was negotiated between GG and the RDB, and then approved by RURA (Rwanda Utilities Regulatory Authority). The PPA included the term 'deemed energy' which obligates REG to pay to GG for the energy that could have been generated in case of a curtailment that occurs under any issue (e.g. grid failure) (Abrams, 2016). The agreed tariff rate is not publicly available, however it is understood to be approximately o.2 USD per Kwh, making it relatively high by international standards for projects of this size. However, this price was less than the existing average wholesale grid price in Rwanda, thus helping to reduce the market price. GG also signed a Concession Agreement with the Ministry of Infrastructure (MININFRA), which established the conditions under which the project could be developed (Abrams, 2016). To reduce investment risk, GG was also granted with a Government Guarantee by the Ministry of Finance and Economic Planning (MINECOFIN), where the government would be responsible of paying for the electricity generated in case REG failed to do so, for whatever reason (Abrams, 2016). Abrams (2016) states that REG was not a creditworthy institution, so the Government Guarantee was a key element on the viability of the project and stood to greatly reduce the financial risk to investors.

From the time GG signed the PPA, it had just six months to secure all the financing. Finding financial partners for the project was a challenging task, but GG reached financial closure on time by February 2014. The PPA was conditional on this very ambitious timeline, due to the urgent need for the country to increase its electricity generation capacity.

The tax exemption for solar projects in Rwanda was a decisive factor for the financing phase of the project. The solar plant had a total investment cost of \$23.7 million, and was financed by an international consortium of debt providers (75\%) and equity investors (25\%). Table 2 summarises the financing consortium for the project. Regarding investment risk, Rwanda currently has very few Bilateral Investment Treaties in force, none with The Netherlands where GG is registered as a legal entity. Consequently, GG decided to rely on agreements - change of law, force majeure, and international arbitration - directly negotiated with the government, and to rely on the purchase of political and currency risk insurance to reduce investment risk (Abrams, 2016). This is not uncommon for such projects in developing countries, though the profile and reputation of Rwanda as a relatively stable political-economic regime was doubtless crucial to securing the private capital investment. Credit enhancements were also considered as an investment risk mitigation mechanism, to compensate the lack of creditworthiness of REG in terms of future payments. The government guarantee that 
was granted was considered sufficient to obtain the debt and equity from the financing partners. It was not accompanied by a liquidity support (i.e. a Letter of Credit) commonly required in power projects in SSA - due to the good investment grade rating and lower risk profile of the country (Abrams, 2016).

Table 2. Summary of the financing consortium (Norfund, s.a.a; Norfund, s.a.b; EAIF, s.a.; McKinsey, 2014).

\begin{tabular}{l|c|c}
\multicolumn{1}{c|}{ Investor } & $\begin{array}{c}\text { Amount } \\
(\$ \text { million })\end{array}$ & Instrument \\
\hline $\begin{array}{l}\text { Scatec Solar, an independent solar power producer } \\
\text { headquartered in Norway }\end{array}$ & $\approx 3.5^{*}$ & $\begin{array}{c}\text { Equity (lead equity } \\
\text { investor) }\end{array}$ \\
\hline $\begin{array}{l}\text { Norfund, the Norwegian Investment Fund for } \\
\text { Developing Countries }\end{array}$ & $\approx 2.61$ & $\begin{array}{c}\text { Equity and } \\
\text { mezzanine loan }\end{array}$ \\
\hline $\begin{array}{l}\text { KLP-Norfund, the largest pension fund in Norway that } \\
\text { co-invests together with Norfund }\end{array}$ & $\approx 1.73$ & Equity \\
\hline $\begin{array}{l}\text { FMO, the Dutch development bank } \\
\begin{array}{l}\text { EAIF (Emerging Africa Infrastructure Fund), a public } \\
\text { private partnership }\end{array}\end{array}$ & 10.6 & $\begin{array}{c}\text { Senior debt } \\
\text { financing }\end{array}$ \\
\hline $\begin{array}{l}\text { ACEF (Africa Clean Energy Finance Initiative), part of } \\
\text { the US government's Power Africa initiative }\end{array}$ & 0.40 & Grant \\
\hline $\begin{array}{l}\text { EEP, Energy and Environment Partnership, an EU- } \\
\text { funded programme which promotes renewable energy, } \\
\text { energy efficiency, and clean technology investments }\end{array}$ & 0.30 & Grant \\
\hline${ }^{*}$ Estimated & &
\end{tabular}

The construction of the project was relatively fast, taking only six months. The plant was constructed on land owned by the ASYV, who is leasing the land to GG. The leasing fee covers approximately $10 \%$ of the expenses of the village, understood to provide a greater income compared to its previous use in agriculture. The project successfully reached Commercial Operation Date (COD) in July 2014, when the interconnection to the grid was completed, but it was not until September 2014 that it became fully operational.

\section{The Rwamagana plant as niche starter}

New market niches based on renewable energies differ radically from previous market niches in developing countries (Schot \& Geels, 2008). On one hand, it may be that previously there was no alternative technology in play, so the new market niche is filling a gap. On the other hand, the new market niche may be better in terms of implementation, economics, etc. than the existing ones.

In the case of the Rwamagana solar power plant, its initial purpose was to rapidly increase power generation capacity in Rwanda, and the renewable nature of the technology was considered a co-benefit. A couple of years after its construction and as a result of an increase in the electricity capacity thanks to the Kivuwatt project, more large-scale solar projects could contribute to increasing the renewable energy share in the energy mix. However, given the structural limitations this kind of project in Rwanda, the Rwamagana project was often viewed as a 'demonstration project' by local stakeholders. Indeed it is clear that large-scale on-grid solar projects are not an established niche in Rwanda. However, it is interesting to note the pace at which the 
project was established. There were no pilots or demonstration projects prior to Rwamagana solar project, thus is has been portrayed in various communications as part of a market-driven shift towards low-carbon energy technologies in Rwanda.

The off-grid solar power market in Rwanda is far more developed than the ongrid large-scale market, and recent strategies plan to increase the role and importance of this technology. In our analysis of the Rwamagana solar project the relationship between these two markets seems to be very weak or non-existent.

First of all, firms that develop large-scale projects and those that install off-grid solutions are specialized in their fields and do not compete in each other's markets. Rwamagana's project developer only develops large-scale projects - e.g. 40 MW in Kenya (Gigawatt Global, 2016). Mobisol - the leading off-grid solutions provider in Rwanda - does not develop large-scale projects; it only focuses on solar home systems (Mobisol, s.a.).

As the operation of large-scale on-grid solar power plants and off-grid systems is very different, the skills and capacities required to drive the market also differ. In the Rwamagana power plant, there are two (Rwandan) technicians working full time to keep the plant up and running. They were previously working in similar power plants in South Africa and acquired specific experience in the operation and maintenance of large on-grid solar PV. Meanwhile, the technical skills required to install, operate and maintain solar home systems are more generic and commonly available. As such, onand off-grid PV solutions do not compete as they operate in different markets, at least while the grid infrastructure under-developed. However, large-scale solar projects do compete with other large-scale technologies, such as hydropower or biogas power plants.

\section{Discussion}

\section{A transition pathway?}

Interactions between the different socio-technical levels determine the transition pathway of the energy transition, which in this article focuses on the development of large-scale on-grid solar projects in Rwanda.

During the last two decades, several disruptive pressures occurred in Rwanda. The need to generate more electricity has been a consequence of the significant population increase and rapid economic growth and development. Additionally, global climate change agreements and national policy is driving the use of renewable energies, which has been also strengthened by the uncertainty of oil prices. However, despite these pressures the electricity regime is fairly stable (with hydropower being the predominant source) in Rwanda. As such, the on-grid solar power niche is not necessarily challenging or disrupting the existing regime. Instead, the regime occupies this new niche within its ambit, allowing multiple regimes co-exist.

Consequently, actors at the regime level have changed and new institutions have been established, facilitating the development of large-scale solar power projects. After the liberalisation of the Rwandan energy market, the IPP option was introduced, allowing the participation of (foreign) private companies in the electricity generation sector.

$\mathrm{RDB}$, the investment promotion agency, plays an important role in the promotion of these projects in terms of private foreign investor participation. However, 
the role of the government as a whole has been crucial in reacting to the landscape pressures by modifying its development path and innovation activities.

Changes in the rules and regulations were not specifically designed for the development of large-scale solar projects but for any energy generation project, promoting solar energy projects through technology-neutral incentives. However, this fact benefits the development of the large-scale on-grid solar niche-market, as it is dependent on the development of other niche-markets - which could also act as a lockin mechanism. In other words, the prospects of implementing more large-scale on-grid projects are closely linked to the development of other electricity generating projects based on non-intermittent energy.

Currently in Rwanda there is just one large-scale solar power plant, and the implementation of new projects looks challenging in the near-future as other projects are being implemented. Regarding solar, the government is particularly focused on promoting off-grid solar solutions to provide electricity access to rural population, given the far higher cost of delivering grid-based power. Therefore, the niche-market for large scale PV has not been sufficiently developed yet in Rwanda, and the Rwamagana project appears to be, for now, a niche-level experiment. The favourable environment still needs to be established - e.g. adequate infrastructure -, but experimental projects are the first step towards the development of a niche (Weber et al., 1999).

All this indicates that the 'transition pathway' which is currently taking place corresponds to the transformation pathway, as characterised by Verbong \& Geels (2010). They state that the hierarchy in the transformation scenario in terms of policy goals is first cost-efficiency, then reliability and finally environmental issues, which coincides with the direction that Rwanda is taking in terms of electricity generation. However, in the near or mid-term future, the transition pathway might change to the reconfiguration pathway as the landscape pressure might become stronger, especially pressures from the international community to prevent large carbon emissions, and to reduce poverty.

\section{Hi-level Political Intervention and Decision-Making in the Transition Process}

Our analysis indicates the central importance of the Rwanda government (political) and state mechanisms (bureaucratic) in enabling the Rwamagana project. Indeed, government support, both politically and financially, and through its provision of legal guarantees that helped reduce investment risk was a fundamental determinant. By documenting and breaking down these processes, and how they interact with, and were shaped by, the role of private sector project developers and foreign investors (both public and private), we are able to explore the manifestations of politics and political will at play in the early stages of the energy transition in Rwanda.

\section{Controversial democracy and long-term mandates}

To shed light on the role and importance of government politics in Rwanda, it is necessary first to understand the system of government under which the country is ruled. Rwanda has officially been a democracy since 2003 and Paul Kagame, member of the Rwandan Patriotic Front (RPF), has been the President since then. Although Rwanda is officially a democracy, the ruling political party, the RPF, has no established opposition (Reyntjens, 2013; DRN, s.a.). Only one opposition party succeeded in 
registering for the last presidential elections in 2010, the Parti Social (PS)-Imberakuri. Other parties failed in their attempt "as a result of systematic sabotage" (Reyntjens, 2013, p.47).

This characteristic appears to be beneficial for reaching Rwanda's main goals of economic development and poverty reduction, as since the end of the genocide, its economic development has stood out, against most of its neighbouring African countries. The government of Rwanda is both praised and criticized. On one hand, highprofile figures such as Tony Blair and Bill Clinton, together with most aid agencies, are 'Friends of the New Rwanda', basing their positive view on the rapid development of the country. On the other hand, "most of academic observers" have a more critical view (Reyntjens, 2013, p.xiii).

However, Reyntjens (2013), openly critical of the government of Rwanda, highlights the government's success in modernising the country - which includes investment in high-tech clean and renewable energy technologies. He states that "when the Rwandan government wants something, it wants it immediately, and it sets close and clear deadlines" (Reyntjens, 2013, p.166).

As such, the Rwandan governance could be described as technocraticauthoritarian, as decisions are based on the most efficient option and do not rely on people's opinion, which is consulted only during presidential elections that have secured high levels of official support. The government of Rwanda has expressed in the Green Growth and Resilience Strategy (Republic of Rwanda, 2011) its commitment to scale up investment in renewable energy technologies, thus maintaining the status quo - i.e. use of fossil fuels - does not appear part of the government's agenda.

The second distinctive trait of the government of Rwanda is Paul Kagame's long term in office. The RPF has been ruling the country since its rebel army ended the genocide in 1994, but it was not until 2000 that Paul Kagame became acting President. He was elected in the first presidential elections in 2003 and re-elected in 2010 (World Bank, 2016a). According to the constitution, presidents cannot rule more than two terms, but in December 2015 the government held a referendum to amend it and allow longer mandates which secured $98 \%$ popular support (BBC, 2016). Paul Kagame was then able to participate in the 2017 elections, and was re-elected president for the third time with $99 \%$ of votes, extending his mandate until 2024 - meaning at least twentyfive years of RPF government (Burke, 2017).

Such long-term mandates present both drawbacks and advantages for the energy transition in the country. First of all, "political opportunities are created for competitive elections and alternations in power" when presidential terms are limited (Riedl, 2015). This can strengthen democracy - and the rule of law - and reduce the possible authoritarian character of the government resulting from long-term mandates (Riedl, 2015). A new President might also revitalise the government's way of doing politics, supporting innovation and allowing for the participation of younger and fresher minds. On the other hand, there is a distinct risk that a change of government will lead to radical change at the regime level (to use the MLP terminology), thus disrupting or otherwise repealing the conditions, rules and regulations that enable specific investment decisions. This translates into uncertainty and risk, pushing up premiums and the demand for higher rates of return by private investors, as it is typical in many other SSA economies. 


\section{Government policy in support of large-scale on-grid solar projects}

The decision of the government to facilitate private sector involvement in the energy was driven by the liberalisation of the energy market, to make it more competitive and economically efficient. The participation of the private sector is also supported by other general strategies such as Vision 2020 and EDPRS II, and other more specific such as ESSP and REP in terms of energy projects.

The government also decided to re-structure and create new agencies such as RDB and REG, focused on promoting private investment and developing energy projects respectively. These agencies were given the required power to fulfil the government's goals.

Decisions on the development of more projects that generate stable energy which enables the introduction of more intermittent energy into the grid -, and the ability of the government to expropriate land are other policies that make possible the development of large-scale solar projects.

The government of Rwanda has particularly supported and shaped the solar energy sector through tax concessions and tariff protection. Regarding the specifics of the Rwamagana solar power plant, tax exemptions helped reduce the cost of the project, but a relatively high tariff and tariff protection was of greater and paramount importance, as articulated by key stakeholders interviewed for this research.

The final agreed tariff prices are especially important as it determined the basic bankability of the project. The rules for PPAs establish a guaranteed price for the electricity generated for a fixed period of time, although the exact price paid is confidential. In effect this offers a FIT-type tariff support, providing a stable income and attractive return on investment. In MLP terms, this kind of tariff (income) support can be seen as an example of niche protection.

The difference between guaranteed prices established on the PPA and FITs are that PPA prices vary, subject to negotiations and are hence specific for each project. As such, the PPA framework opens up significant space for political influence, either in the form of direct government pressure, lobbying and/or commercial negotiation.

In addition to the tariff protection, there were other aspects that motivated investors' willingness to invest in the project. The project was seen as innovative as it was the first large-scale on-grid PV solar project in SSA outside of South Africa, thus offering a degree of prestige. Furthermore, Rwanda is seen as a relatively transparent, politically and economically stable regime. In business terms, the prolonged period of peace reassures future potential investors, and Rwanda's investment environment is currently rated as 'B' by Standard \& Poor's (Trading Economics, 2016).

\section{Fast-track niche development? Temporal dimensions of energy transition}

As discussed in the previous section, transitions to newer, cleaner renewable sources of electricity often require significant shifts not only in technology, but in political support, regulations, tariffs and pricing regimes (Sovacool 2016). The mainstream academic literature suggests that there is a long-time scale involved in triggering and enabling successful transitions. There is a tendency for the new systems 
to face the "lock-in" or "path dependency" of existing systems, which slows down the pace of transitions.

Technological changes take place over a long time-period (Bijker, 1997; Hughes, 1987). Hughes (1987) identified five stages in the evolution of large scale technological system, which corresponds to the characteristics of niche development: invention, research and development, technological transfer, system growth, technological momentum and planned regional systems. Grubler (2003) typified four phases of energy systems comprising of an extended period of experimentation and learning, scaling up at the unit level, scaling up at the industry level, and further industry growth driven by globalization. Independent of these theories, several historical cases suggest longer timeframes for energy systems to transition.

However, contrary to such arguments, there are also examples of rapid nationalscale transitions in energy supply (Sovacool, 2016), in which some nations took 1-3 years to increase the market share of the technology from $1 \%$ to $25 \%$. Examples include flexfuel vehicles in Brazil, crude oil and electricity in Kuwait, combined heat and power in Denmark, etc. Further, in the case of The Netherlands, the transition away from oil and coal to natural gas was rapid, and was strategically steered by the government. Some of these cases have special governance characteristics - communist China, military dictatorship under Brazil, socialist communes in Denmark, etc.

Our observations from Rwanda are limited to one solar power plant, which is only perhaps the beginning of an industry, however, it presents a useful insight into the pace of transitions at the level of utility scale solar in an African context. The project scrutinised in our research did not involve a long gestation period of experimentation, learning and scaling up, partly because the technology is already competitive and available globally. There is better knowledge available on the co-benefits of low carbon energy supply, and the prices for solar panels have stabilised and fallen significantly in recent years.

However, while all of these factors are operating simultaneously, the aggressive leadership of the government in expediting and taking hard top-down decisions cannot be overlooked, which allowed fast-track implementation of the project. While exogenous factors played a role to create favourable conditions, it is the endogenous factors within a country that led to the transition - in the form of political dictatorship, favourable policies, tax incentives, favourable tariff rates, conducive business environment, and most importantly, strong political willing. This case suggests that the gestation periods of technology deployment, transfer and diffusion can be overcome by political force alone. However, it can be questioned if this form of fast-track niche development will actually enable transitions to take shape. Is this a bubble of a nascent industry, lured by profits, low risk (because of government guarantees), and social currency of clean energy; or is this a deliberate attempt to steer the country in a sustainable pathway, while meeting the increasing energy demands.

To frame these issues within the parlance of the multi-level perspective and socio-technical transitions theory, we see the case of Rwandan utility scale solar niches as having evolved without local experiments/demonstrations, without longer periods of deployment, and without challenging or replacing the stable regime. What we have seen is a complex interplay of multi-scalar actors, operating with their respective interests and agendas, steering a single technology/project to market within a relatively short 
period. It remains to be seen if this fast-tracking of a single solar power plant will trigger additional investment, worthy of constituting a true energy transition.

\section{Conclusions}

The change from donor-driven to market-driven solar PV projects that is taking place in SSA is exemplified by the Rwamagana plant in Rwanda. However, the state remains central to enabling, shaping and guiding the market, especially for large infrastructure investments that are traditionally the domain of state control and oversight. The government, the private sector and the investors made this project possible, with a relatively minor contribution from public donors in the form of start-up grants. Good project ideas are a crucial first step, but having a project 'champion' to coordinate and inspire all stakeholders is equally important.

An expression of the government's strong support was the agreement to pay a competitive tariff, negotiated within the PPA. To have confidence in the agreement, the project developer and the investors relied on the Rwandan government as the ultimate guarantor - i.e. that the investors would actually get paid the electricity price initially agreed upon -, and so the rule of law, and faith in public institutions, is important to minimise investor risk. Other key determinants were the clear conditions and the incentives for solar PV technology, which reduced the cost of the project. Rwanda offered favourable conditions to implement solar projects and, more broadly, to do business.

Foreign expertise was also central to the development and implementation of these projects. Rwanda lacks a sufficient number of experienced project developers, solar panel manufacturers, and electrical engineers specialised in these kinds of projects. With regard to the MLP framework, our analysis has focused mainly on the regime and niche levels. The corresponding transition pathways - i.e. transformation and reconfiguration pathways - showed the regime level was affected by the landscape and niche levels, and the interaction between them. We can conclude that the role of power and politics in the development of large-scale on-grid solar projects in Rwanda were the key determinants of this emerging energy 'transition'. More broadly, we argue that there is a need to address this dimension in future applications of the MLP framework, which usually overlook or underplay the importance of politics, especially in the study of energy transitions in developing countries.

\section{References}

Abrams, C., 2016. Rwanda - A Case Study in Solar Energy Investment. Renewable Energy Law and Policy Review, 7 (1), 4 - 19 .

Baker, L., 2012. The political economy of socio-technical transitions in South Africa's electricity sector. PhD Article. University of Sussex.

Baker, L., Newell, P., \& Phillips, J. (2014). The political economy of energy transitions: The case of South Africa. New Political Economy, 19(6), 791-818. 
Baker, L., Newell, P. \& Phillips, J., 2014. The political economy of energy transitions: the case of South Africa. New Political Economy, 1-28.

BBC, 2016. Rwanda's Paul Kagame to run for third presidential term. BBC News. Available at: http://www.bbc.com/news/world-africa-35209186 [Accessed on 01/10/2016].

Bijker, W. E. (1997). Of bicycles, bakelites, and bulbs: Toward a theory of sociotechnical change. MIT press.

Bosmana, R., Loorbacha, D., Frantzeskakia, N., Pistoriusb, T., 2014. Discursive regime dynamics in the Dutch energy transition. Environmental Innovation and Societal Transitions, 13, 45-59.

Burke, Jason, 2017. Paul Kagame re-elected president with 99\% of vote in Rwanda election. The Guardian. Available at: https://www.theguardian.com/world/2017/aug/o5/paul-kagame-secures-thirdterm-in-rwanda-presidential-election [Accessed on 30/11/17]

Bryman, A., 2012. Social Research Methods, 4th Edition. Oxford University Press.

Byrne, R. P. (2011). Learning drivers: rural electrification regime building in Kenya and Tanzania (Doctoral dissertation, University of Sussex).

Byrne, R., Ockwell, D., Urama, K., Ozor, N., Kirumba, E., Ely, A., ... \& Gollwitzer, L. (2014). Sustainable energy for whom? Governing pro-poor, low-carbon pathways to development: lessons from solar PV in Kenya.

DRN, s.a. Democracy in Rwanda Now. Available at: http://www.democracyinrwandanow.org/ [Accessed on $01 / 10 / 2016]$.

EAPP, 2016. Eastern Africa Power Pool. Available at: http://eappool.org/ [Accessed on 15/o8/16].

EAIF, s.a. Gigawatt Global - Benefiting Rwanda. Available at http://eaif.com/our-

projects/view/gigawatt-global-benefitting-rwanda [Accessed on 13/04/16].

Foxon, T. J. (2013). Transition pathways for a UK low carbon electricity future. Energy Policy, 52, 10-24.

Gakwaya, A., 2012. Rwanda seeking private sector role to raise energy production. Rwanda News Agency. Available at http://www.rnanews.com/component/content/article/48-energy-sector/6408rwanda-seeking-private-sector-role-to-raise-energy-production- [Accessed on 03/o7/2016].

Geels, F.W., 2004. From sectoral systems of innovation to socio-technical systems: insights about dynamics and change from sociology and institutional theory. Research Policy 33, 897-920.

Geels, F.W., 2011. The multi-level perspective on sustainability transitions: Responses to seven criticisms. Environmental Innovation and Societal Transitions 1, 24-40.

Geels, F.W., Kern, F., Fuchs, G., Hinderer, N., Kungl, G., Mylan, J., Neukirch, M., Wasserman, S., 2016. The enactment of socio-technical transition pathways: A reformulated typology and a comparative multi-level analysis of the German and UK low-carbon electricity transitions (1990-2014). Research Policy 45 (4), 896-913.

Geels, F.W. and Schot, J., 2007. Typology of sociotechnical transition pathways. Research Policy 36, 399417 .

Gigawatt Global, 2016. Overview. Available at http://gigawattglobal.com/about/overview/ [Accessed on 13/04/16].

Grubler, A., 2012. Energy transitions research: Insights and cautionary tales. Energy Policy, 8-16. 
Hansen, U. E., Nygaard, I., Brix Pedersen, M., 2014. Prospects for investment in large-scale, gridconnected solar power in Africa. UNEP Risø Centre, Department of Management.

Hughes, T. P. (1987). The evolution of large technological systems. The social construction of technological systems: New directions in the sociology and history of technology, 51-82.

IEA (International Energy Agency), 2014. Africa Energy Outlook - A focus on energy prospects in the sub-Saharan Africa.

Interview AE (Afritech Energy), 2016. Personal interview with Dan Klinck by Judit Rodríguez. June 2016, Kigali (Rwanda).

Interview CC (Climate Concern), 2016. Personal interview with Jean Ntazinda by Judit Rodríguez. June 2016, Kigali (Rwanda).

Interview GG (Gigawatt Global), 2016. Personal interview with Chaim Motzen by Judit Rodríguez. August 2016, Skype.

Interview MINIRENA, 2016. Personal interview with Peter Katanisa by Judit Rodríguez. June 2016, Kigali (Rwanda).

Interview REG-a, 2016. Personal interview with Anicet Nsengiyumva by Judit Rodríguez. July 2016, Kigali (Rwanda).

Interview REG-b, 2016. Personal interview with James Twesigye by Judit Rodríguez. July 2016, Kigali (Rwanda).

Interview RDB, 2016. Personal interview with Olivier Ngororabanga by Judit Rodríguez. June 2016, Kigali (Rwanda).

Interview SS (Scatec Solar), 2016. Personal interview with Twaha Twagirimana by Judit Rodríguez. June 2016, Rwamagana (Rwanda).

Interview TG (Trevor Green), 2016. Personal interview with Trevor Green by Judit Rodríguez. June 2016, Kigali (Rwanda).

Jacobsson, R., 2013. The diffusion of solar PV technology using TIS perspective - a case study of Rwanda. Master Article. VU University Amsterdam.

Jolly, S., Raven, R., Romijn, H., 2012. Upscaling of business model experiments in off-grid PV solar energy in India. Sustainability Science, 7(2), 199-212.

Kagera, T., 2016. Rwanda: 2015/2016 Infrastructure Sector Achievements and 2016/17 Targets. All Africa. Available at: http://allafrica.com/stories/201610030518.html [Accessed on 08/10/2016].

Kern, F., 2012. Using the multi-level perspective on socio-technical transitions to assess innovation policy. Technological Forecasting \& Social Change, 79, 298-310.

Marquardt, J., Steinbacher, K., Schreurs, M., 2015. Driving force or forced transition? The role of development cooperation in promoting energy transitions in the Philippines and Morocco. Journal of Cleaner Production, 1- 12.

McKinsey, R., 2014. Israeli group kicks off \$23m energy project in Rwanda. The Times of Israel. Available at: http://www.timesofisrael.com/israeli-group-kicks-off-23m-energy-project-in-rwanda/ [Accessed on $27 / 06 / 2016]$. 
MINECOFIN, 2013. Economic Development and Poverty Reduction Strategy II 2013-2018. Republic of Rwanda.

MININFRA, s.a. Solar Energy in Rwanda. Republic of Rwanda. Available at: http://www.mininfra.gov.rw/index.php?id=85 [Accessed on 10/03/2016].

MININFRA, 2015a. Rwanda Energy Policy. Republic of Rwanda.

MININFRA, 2015b. Energy Sector Strategic Plan (2013/14-2017/18). Republic of Rwanda.

Mobisol, s.a. Mobisol. Available at: http://www.plugintheworld.com/mobisol/ [Accessed on 15/o9/2016].

Mohamad, Z.F., 2011. The emergence of fuel cell technology and challenges for catching-up by latecomers: Insights from Malaysia and Singapore. International Journal of Technology and Globalisation, 5(3/4), 306.

Museruka, C. and Mutabazi, A., 2007. Assessment of Global Solar Irradiation over Rwanda. Proceedings of the International Conference on Clean Electrical Power (ICCEP).

Newell, P., Phillips, J., Pueyo, A., Kirumba, E., Ozor, N., \& Urama, K. (2014). The political economy of low carbon energy in Kenya. IDS Working Papers, 2014(445), 1-38.

NISR, 2012. Fourth Population and Housing Census, Rwanda 2012. Final Results - Main Indicators Report. National Institute of Statistics of Rwanda and Ministry of Finance and Economic Planning.

Norfund, s.a.a. Scatec Solar Rwanda. Available at: http://www.norfund.no/eastern-africa/scatec-solarrwanda-article1092-319.html [Accessed on 13/04/16].

Norfund, s.a.b. KLP Norfund Investments AS (KNI). Available at: http://www.norfund.no/regionalglobal/klp-norfund-investments-as-kni-article1338-411.html [Accessed on 13/o4/16].

Parliament of Rwanda, 2011. Law n²1/2011 of 23/o6/2011 governing Electricity in Rwanda. Official Gazette of the Republic of Rwanda, $n^{\circ}$ Special of 12/o7/2011.

Parliament of Rwanda, 2013. Law nº37/2012 of 09/11/2012 establishing the value added tax. Official Gazette of the Republic of Rwanda, $\mathrm{n}^{\circ}$ Special of 05/02/2013.

Parliament of Rwanda, 2015a. Law n॰ 06/2015 of 28/03/2015 relating to Investment Promotion and Facilitation. Official Gazette of the Republic of Rwanda, no Special of 27/05/2015.

Parliament of Rwanda, 2015b. Law nº34/2015 of 30/06/2015 establishing the infrastructure development levy on imported goods. Official Gazette of the Republic of Rwanda, no Special of 01/o7/2015.

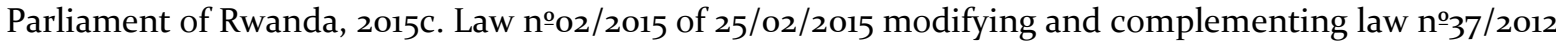
of 09/11/2012 establishing the value added tax. Official Gazette of the Republic of Rwanda, $\mathrm{n}^{\circ} 11$ bis of $16 / 03 / 2015$.

Poole, M.S. and Van de Ven, A.H., 1989. Towards a general theory of innovation processes. In: Van de Ven, A.H., Angle, H.L., Poole, M.S. (Eds.), Research on the Management of Innovation: The Minnesota Studies. Harper \& Row Publishers, New York, NY, pp. 637-662.

Pueyo, A. (2015). Pro-Poor Access to Green Electricity in Kenya (No. IDS Evidence Report; 135). IDS.

REG (2017). Current Status of Power Generation in Rwanda. Available at: http://www.reg.rw/index.php/projects/generation/744-current-status-of-power-generation-in-rwanda [Accessed on 12/09/17] 
Republic of Rwanda, 2011. Green Growth and Climate Resilience, National Strategy for Climate Change and Low Carbon Development.

Republic of Rwanda, 2012. Rwanda Vision 2020 - Revised 2012.

Reyntjens, F., 2013. Political Governance in post-Genocide Rwanda. Cambridge University Press.

Riedl, R.B., 2015. The advantages - and drawbacks - of presidential term limits as a tool for building democracy in Africa. SSN Key Findings. Available at:

http://www.scholarsstrategynetwork.org/brief/advantages-and-drawbacks-presidential-term-limitstool-building-democracy-africa [Accessed on 02/11/2016].

RURA, 2012. The Rwanda Grid Code.

RURA, 2016. Key Statistics in Electricity Sub-Sector as of December 2015. Economic Regulation Unit.

RURA, 2016. Decision No 05/BD/ER-LER/RURA/2016.

Scatec Solar, 2014. Scatec Solar and Norfund begin construction on East Africa's First Utility-Scale. Available at http://www.scatecsolar.com/About/Press-and-media/Press-releases/Scatec-Solar-andNorfund-begin-construction-on-East-Africa-s-First-Utility-Scale [Accessed on 13/04/16].

Schot, J. and Geels, F, 2008. Strategic niche management and sustainable innovation journeys: theory, findings, research agenda, and policy. Technology Analysis \& Strategic Management, 20 (5), 537-554.

Sovacool, B. K. (2016). How long will it take? Conceptualizing the temporal dynamics of energy transitions. Energy Research \& Social Science, 13, 202-215.

Strunz, S., 2014. The German energy transition as a regime shift. Ecological Economics, 100, 150-158.

Tigabu, A., Berkhout, F., van Beukering, P., 2015. Technology innovation systems and technology diffusion: Adoption of bio-digestion in an emerging innovation system in Rwanda. Technological Forecasting and Social Change, 9o (A), 318-330.

Trading Economics, 2016. Rwanda - Credit Rating. 9th September 2016. Available at: http://www.tradingeconomics.com/rwanda/rating [Accessed on 10/10/2016].

Ulsrud, K., Winther, T., Palit, D., Rohracher, H., Sandgren, J., 2011. The solar transitions research on solar mini-grids in India: Learning from local cases of innovative socio-technical systems. Energy for Sustainable Development, 15(3), 293-303.

Ulsrud, K., Winther, T., Palit, D., \& Rohracher, H. (2015). Village-level solar power in Africa: accelerating access to electricity services through a socio-technical design in Kenya. Energy Research \& Social Science, 5, 34-44.

Verbong, G. and Geels, F., 2007. The ongoing energy transition: Lessons from a socio-technical, multilevel analysis of the Dutch electricity system (1960-2004). Energy Policy, 35, 1025-1037.

Verbong, G. and Geels, F., 2010. Exploring sustainability transitions in the electricity sector with sociotechnical pathways. Technological Forecasting and Social Change, 77, 1214 - 1221.

Wassermann, S., Reeg, M., Nienhaus, K., 2015. Current challenges of Germany's energy transition project and competing strategies of challengers and incumbents: The case of direct marketing of electricity from renewable energy sources. Energy Policy, 76, 66-75.

Weber, M., R. Hoogma, B. Lane, J. Schot, 1999. Experimenting with Sustainable Transport Innovations. A workbook for Strategic Niche Management, Seville/Enschede. 
World Bank, 2012a. Access to electricity, urban (\% of urban population) - Rwanda. Available at: http://data.worldbank.org/indicator/EG.ELC.ACCS.UR.ZS [Accessed on 16/05/2016].

World Bank, 2012b. Access to electricity, rural (\% of rural population) - Rwanda. Available at: http://data.worldbank.org/indicator/EG.ELC.ACCS.RU.ZS [Accessed on 16/05/2016].

World Bank, 2014. Population density. Available at:

http://data.worldbank.org/indicator/EN.POP.DNST?order=wbapi_data_value_2014+wbapi_data_value+ wbapi_data_value-last\&sort=desc [Accessed on 16/05/2016].

World Bank, 2015. GDP per capita (current US\$). Available at:

http://data.worldbank.org/indicator/NY.GDP.PCAP.CD [Accessed on 19/o7/2016].

World Bank, 2016a. Rwanda: Overview. Available at:

http://www.worldbank.org/en/country/rwanda/overview [Accessed on 23/05/2016].

World Bank, 2016b. Doing Business 2016 Report - Measuring Regulatory Quality and Efficiency. 13th Edition. 